This is an electronic reprint of the original article. This reprint may differ from the original in pagination and typographic detail.

Author(s): Lehesvuori, Sami; Viiri, Jouni; Rasku-Puttonen, Helena

Title: Introducing Dialogic Teaching to Science Student Teachers

Year: $\quad 2011$

Version:

Please cite the original version:

Lehesvuori, S., Viiri, J., \& Rasku-Puttonen, H. (2011). Introducing Dialogic Teaching to Science Student Teachers. Journal of Science Teacher Education, 22(8), 705-727. https://doi.org/10.1007/s10972-011-9253-0

All material supplied via JYX is protected by copyright and other intellectual property rights, and duplication or sale of all or part of any of the repository collections is not permitted, except that material may be duplicated by you for your research use or educational purposes in electronic or print form. You must obtain permission for any other use. Electronic or print copies may not be offered, whether for sale or otherwise to anyone who is not an authorised user. 


\title{
INTRODUCING DIALOGIC TEACHING TO SCIENCE STUDENT TEACHERS
}

\section{Sami Lehesvuori, Jouni Viiri \& Helena Rasku-Puttonen}

\begin{abstract}
It is commonly believed that science teachers rely on language that allows only minor flexibility when it comes to taking into account contrasting views and pupil thoughts. Too frequently science teachers either pose questions that target predefined answers or simply lecture through lessons, a major concern from a sociocultural perspective. This study reports the experiences of science student teachers when introduced to the Communicative Approach to science education drawing on dialogic teacher-talk in addition to authoritative teacher-talk. This approach was introduced to the students in an interventional teaching program running parallel to the student teachers' field practice. The practical implications of this approach during initial teacher education are the central focus of this study. The data consisting of videos of lessons and interviews indicate that the student teacher awareness of teacher-talk and alternative communicative options did increase. Student teachers reported greater awareness of the different functions of teacher-talk as well as the challenges when trying to implement dialogic teaching.
\end{abstract} Keywords: Science teacher education; teacher-talk; dialogic teaching; Communicative Approach 


\section{Introduction}

The importance of productive classroom practices leading to positive learning outcomes is widely acknowledged and the teacher's role in promoting dialogic interaction has been demonstrated in many previous studies (Littleton \& Howe, 2009; Mortimer \& Scott, 2003; Wells \& Arauz, 2006). While learning is likely to be most effective when children engage in the cognitive restructuring of their own knowledge and understanding (e.g., Wells, 2007) moving towards more dialogic teaching is challenging, especially for science teachers (Scott, Mortimer, \& Aguiar, 2006). As improvements in schools are assumed to result from changes in teacher education, demands for improvements in teacher education have increased and the ways in which teachers are educated have been challenged (Bransford, Darling-Hammond, \& LePage, 2005). In response to this demand, this study explores science student teachers' experiences of dialogic teaching and the practical implications of dialogic teaching during initial teacher education.

In response to the sociocultural view of teaching and learning, researchers have introduced the concept of 'dialogic teaching' (e.g., Alexander, 2006; Nystrand, Gamoran, Kachur, \& Prendergast, 1997). Dialogic teaching differentiates conversation from dialogue in terms of what follows from pupil answers (Alexander, 2006). In dialogic teaching exchanges are chained into coherent lines of enquiry rather than left disconnected. In science, dialogic teaching can be understood, not only as supportive and reciprocal interaction between participants in the classroom but as teachers orchestrating the dialogue between diverging ideas, for example, between everyday views and science's views (Lemke, 1990; Mortimer \& Scott, 2003). To characterize these different forms of classroom talk and to provide a tool for the effective orchestration of classroom interaction, Mortimer and Scott (2003) developed the concept of the Communicative Approach particularly relevant to science education. This framework consists of 
four classes generated from two dimensions: interactive/non-interactive and authoritative/dialogic. The first dimension allows for student participation through interactive talk whereas non-interactive talk is monologic indicative of, for example, a lecture. The second dimension introduces the dialogic approach which takes into account diverging ideas and the authoritative approach which focuses on a specific point of view, usually the science view, presented by the teacher. The combination of these two dimensions forms the concept of Communicative Approach (CA) of Mortimer and Scott (2003).

While authoritative approaches are relatively easily found within science education research and hold an important place in classroom communication, dialogic approaches are more uncommon (Mercer, Dawes, \& Staarman, 2009). Nevertheless, elements of dialogic teaching, such as questioning to stimulate and extend pupils’ thinking (Chin, 2007) and elaborating on pupil responses, have been reported as valuable motivational factors in science education. When pupils have opportunities to present and challenge their pre-existing views against the scientific view, pupils can more easily see the lack in their understandings and are more willing to adopt new insights (Posner, Strike, Hewson, \& Gertzog, 1982). Scott and Ametller (2007) suggest that the meaningful learning of science involves teachers creating space for dialogic discussion before introducing and concluding the discussion with the authoritative voice of science. Indeed some preliminary results indicate that combining authoritative and dialogic approaches is the most beneficial for pupils’ learning outcomes (Furtak \& Shavelson, 2009).

The focus in teacher education has been shifting towards more pupil-centred teaching methods (e.g., Peters, 2010), however, observation studies reveal minor changes in the field. Classroom interaction is still commonly dominated by lecturing or closed questions followed with evaluative feedback (e.g., Mercer et al., 2009; Molinari \& Mameli, 2010) typically 
defined as the IRF-pattern, in which $I$ stands for teacher's initiation, $R$ for pupil's response and $F$ (sometimes E for evaluation) for teacher's feedback (Lemke, 1990; Sinclair \& Coulthard, 1975). In order to expand and vary the classic lecture and transmission modes of science education, inadequate for developing pupil understanding, teacher education needs ways of teaching teachers in the field of classroom interaction (Crespo, 2002). Arguably this is a lifelong process, but in order to initiate this development, the theory and practice within this field should first be introduced during pre-service training. Pre-service training is especially important if this is the most effective way of introducing change into in-service teaching practice (Bransford et al., 2005). Although learning to teach is a complex process, steps should be taken to develop teaching programs to give novice-teachers the opportunity to learn and practice alternative forms of teaching (Graber, 1996).

Pre-service teacher perceptions of teaching are largely based on their own experiences in school as pupils (Abell, 2000). Unless these perceptions are explicitly addressed, the danger exists that these beliefs persist throughout teacher education and into in-service teaching (Fajet, Bello, Leftwich, Mesler, \& Shaver, 2005). Lecture-based professional development programs which 'transmit' knowledge and lack integrated instruction (Abell, 2000) often fail to access student teachers' pre-existing needs for professional development (Chval, Abell, Pareja, Musikul, \& Ritzka, 2008). Traditional approaches to science education foregrounding the authoritative voice can effectively quash attempts to develop dialogic interaction if the role of dialogic interaction is insufficiently addressed. In response to these concerns, the specific aim of the teaching program on dialogic practices was to explicitly bring forth student teachers' pre-existing views on teaching and learning, and to provide opportunities 
for the discussion and practice of new pedagogical insights within the context of the Communicative Approach.

Research on social aspects of science teaching in professional development programs is limited. One example, however, is Oliveira's (2009) examination of how elementary teachers' increased awareness of inquiry-based questioning influenced their behavior. Oliveira's study indicated that teachers became far more aware of the different functions questions can serve. The elementary teachers recognized that in addition to serving cognitive ends questions also serve social functions, for example, encouraging pupils to articulate their own ideas. Teachers used questions that included social aspects twice as frequently following the two-week intervention. Another social aspect of teaching which has been studied is the 'neutral acknowledgment' of pupil responses to foster pupils' exploration of different points of view and to encourage pupils to keep talking (van Zee, Iwasyk, Kurose, Simpson, \& Wild, 2001). These non-evaluative, neutral and supportive features of question-based discourse are perhaps the most accessible practices of dialogic teaching and are a focal point of the study reported here too. This study also addressed the need to provide student teachers with opportunities to examine and practice dialogic elements of teacher-talk, such as neutral questioning, during pre-service (Mortimer \& Scott, 2003; Orland-Barak \& Yinon, 2007). Although preliminary results indicate that student teacher communications can be enriched when purposefully guided (Viiri \& Saari, 2006), few studies report on teacher education programs and method courses specifically addressing how teacher-talk can be taught to student teachers and practiced during pre-service. Furthermore, the ways student teachers embrace the content of innovative teaching programs both in theory and practice is also insufficiently addressed. It is this lack that the present study hopes to address. 


\section{Research Questions}

Previous studies on science professional development programs provide important insights into aspects such as designing appropriate lessons, adopting effective teaching methods, following particular instructional activities, and evaluating student learning (e.g., Akerson \& Hanuscin, 2007; Luera \& Otto, 2005). However, one limitation of these programs is that they often overlook the social dimension of science teaching (Oliveira, 2009; Oliveira, 2010) and the integration into instruction (e.g., Borko, 2004; Clarke \& Hollingsworth, 2002; Yilmaz-Tuzun, 2008). When these social and integrative dimensions are overlooked, student teachers are often unable to effectively use the appropriate pedagogical strategies highlighted in methods courses.

In this study the aim was to explicitly address these social and integrative dimensions in pre-service science teacher education. These dimensions come together in the dialogic focus of this study with the research questions:

1) How did student teachers plan and implement dialogic teacher-talk in science education during their pre-service field practice?

2) How did student teachers experience dialogic interaction and its implementation?

In general terms we see this focus on dialogic teaching as being fundamentally important to bring forth in the context of science teacher education.

\section{Method}

\section{The Context and the Participants}

The context of this study includes three facilities of the University: the Department of Teacher Education, the Teacher Training School, and the Physics Department. The researchers themselves belong to the Department of Teacher Education responsible for the pedagogical studies for subject and class teacher education at the university. It was under the auspices of the Teacher 
Education Department that the first author planned and executed the dialogic teaching program. The tutor teachers are staff of the Teacher Training School responsible for overseeing the field practice of student teachers. The student teacher participants belonged to both the Department of Teacher Education and the Physics Department as during pre-service teacher training subject and pedagogical studies are conducted in parallel. The one-year pedagogic period includes the necessary pedagogical studies to qualify students as subject teachers after finishing their Master's degree. Student teachers may have some experience as substitute teachers prior to their teacher education, but many student teachers start their pedagogical studies with no teaching experience. Student teachers usually study their major subject, alongside other minor subjects such as mathematics and chemistry, for three-four years prior to teacher education.

At the beginning of the academic year of 2007-2008 (Oct-May), the dialogic teaching program was introduced in general to all of the 15 student physics teachers and the invitation for volunteers was made. Six individuals volunteered after the introductory session and Anthony, David, Kevin, Maria, Paul and Susan completed the dialogic teaching program as presented in the left column of Table 1.

In the following academic year (2008-2009), 6 physics student teachers, George, Rosanna, Lea, Mark, Melanie, and Joanna, were introduced to the improved teaching program in an information session. All of the students volunteered, although Lea joined with the proviso not to be video-recorded. In total, 12 out of 21 physics student teacher voluntarily participated in the teaching program during semesters 2007-2008 and 2008-2009. All of the names are pseudonyms in order to maintain absolute anonymity. When selecting the pseudonyms common English names were chosen to help international readers identify the gender of the participants. The participants provided written permission to present the data related to this project. 


\section{The Teaching Program}

The aim of the teaching program on dialogic practices was to explicate the student teachers' preexisting views on teaching and learning, and to provide the student teachers with opportunities to discuss and practice new pedagogical insights via various activities. This teaching program did not intend to model complex reflective instructional decision-making and planning (Schön, 1983), rather the aim of the intervention was to explicitly address the developing views of the student teachers. The phases, duration and related activities of the program are listed in Table 1.

Table 1 Phases and activities of the teaching program

\begin{tabular}{|c|c|}
\hline $\begin{array}{l}\text { Phases and Activities of the } \\
\text { Teaching Program 2007-2008 }\end{array}$ & $\begin{array}{c}\text { Related activities and } \\
\text { improvements for the semester } \\
2008-2009\end{array}$ \\
\hline $\begin{array}{l}\text { Theory } \\
\text { - Instruction including theoretical } \\
\text { background and the CA concept } \\
\text { (2 hours) }\end{array}$ & $\begin{array}{l}\text { Improvement: } \\
\text {-Video clips from semester 2007- } \\
2008\end{array}$ \\
\hline $\begin{array}{l}\text { Observations } \\
\text { - Two teaching sessions. One } \\
\text { physics lesson taught by peer } \\
\text { and } 1 \text { lesson by tutor teacher in } \\
\text { teacher training school } \\
\text { - Written report by student } \\
\text { teacher on observations } \\
\text { - Group discussion between } \\
\text { researcher and the student } \\
\text { teachers on the observations (2 } \\
\text { hours) }\end{array}$ & $\begin{array}{l}\text { Improvement: } \\
\text {-Improved observation forms and } \\
\text { instructions for classroom } \\
\text { observations }\end{array}$ \\
\hline $\begin{array}{l}\text { Planning and Implementing } \\
\text { - Two physics teaching sessions } \\
\text { including written lesson plans } \\
\text { completed by individuals } \\
\text { following the instructions of the } \\
\text { researcher }\end{array}$ & $\begin{array}{l}\text { Improvement and Related activity: } \\
\text {-Peer videoing }\end{array}$ \\
\hline $\begin{array}{l}\text { Reflections } \\
\text { - Guided reflective feedback } \\
\text { sessions with the researcher } \\
\text { based on the stimulated recall } \\
\text { interview technique after each } \\
\text { teaching session } \\
\end{array}$ & \multirow{2}{*}{$\begin{array}{l}\text { Related activity: } \\
\text {-Small scale research } \\
\text { - } \quad \text { About teacher-talk using the } \\
\text { CA and video data from } \\
\text { student teacher lessons (own \& } \\
\text { others') } \\
\text { - Supervised by the physics } \\
\text { pedagogue } \\
\text { Both semesters }\end{array}$} \\
\hline $\begin{array}{l}\text { Group interview ( } 2 \text { hours) } \\
\text { - Discussions between researcher } \\
\text { and student teachers about the } \\
\text { teaching program and the CA } \\
\text { concept }\end{array}$ & \\
\hline
\end{tabular}


The general aim of the program was to maintain the presence and practice of the CA during each phase (e.g., theoretical instructions, practical activities, and reflective feedback sessions). The basis of the teaching program was the same for both periods (2007-2008 \& 20082009) although using the results of 2007-2008 a number of small improvements were made, as presented in Table 1. One change was that instead of the researcher video-recording the student teacher lessons, the videoing was done by peers. The peer-videoing reduced the evaluative atmosphere during the implementation phase, an improvement suggested by the student teachers. This change in turn created the opportunity for the student teachers to be empirical researchers of their own professional development, which may provide "a catalyst for reflection and critical dialogue among student teachers” (Hartford \& MacRuairc, 2008, p. 1890).

Another significant change in the second teaching program, and surely an improvement, was the inclusion of the video database from the 2007-2008 semester. Selected authentic video clips were used during the theory phase. The student teachers first commented on the clips prior to being introduced to the CA concept and then again once familiarized with the CA concept. Videos were used as they especially capture the richness of classroom events (Brophy, 2004; Rosaen, Lundeberg, Cooper, Fritzen, \& Terpstra, 2008) and can be effectively used for later analysis. Videos have also been successfully used to create an environment in which to engage teachers in productive discussions about teaching and learning, in order to foster professional development (Borko, Jacobs, Eiteljorg, \& Pittman, 2008; Hartford \& MacRuairc, 2008).

The first author provided the student teachers with guidance and tutoring in general, but had no input regarding the content and execution of the lessons apart from providing a basic structure for planning episodes and teacher-talk. The structure for planning the episodes was 
derived from the analytical framework for analyzing science teaching interaction developed by Mortimer and Scott (2003). This structure includes the consideration of the topic, purpose, implementation and communicative approach. Whereas David did not follow this structure in his lesson plan, Paul's lesson plan illustrates this structure in Appendix A. Within this structure explicit question prompts are not written down, rather the implementation of this dialogic approach requires teachers to pre-consider open questions and to anticipate the need for supportive or neutral feedback. The lessons were conducted under the supervision of the tutor teacher usually without any intervention or support. Based on the first author's own experiences as a student physics teacher with the same tutors and the interview with the collaborating tutor teacher Mr. James, dialogic teaching is not explicitly addressed by the teacher training school.

\section{Data Collection and Analysis}

This paper includes the analysis and presentation of data as shown in Table 2. The complete dataset was analyzed and the cross-sectional view of the data presented here is intended to allow the exemplification and discussion of the overall project within the limitations of an article. The findings are, therefore, presented at both cross-case and collective levels. The illustrative examples of individual student teachers presented and discussed below are then the focus of the summaries of the collective experiences of the student teachers. These collective experiences emerged as the group discussed their observations as well as in the group interview which included all of the participants of the semester. 
Table 2 Data analysis and presentation

\begin{tabular}{|c|c|c|c|}
\hline Research question & Data analyzed & Data example & $\begin{array}{l}\text { Analytical } \\
\text { methods }\end{array}$ \\
\hline \multirow{2}{*}{$\begin{array}{l}\text { 1) How did student } \\
\text { teachers plan and } \\
\text { implement dialogic } \\
\text { teacher-talk during } \\
\text { their pre-service field } \\
\text { experience? }\end{array}$} & $\begin{array}{l}\text { All video-recorded } \\
\text { lessons including } \\
\text { lesson plans }\end{array}$ & $\begin{array}{l}\text { Dialogic episodes and } \\
\text { lesson plans of David } \\
\text { and Paul and summary } \\
\text { of all student teachers }\end{array}$ & \multirow{4}{*}{ Video analysis } \\
\hline & $\begin{array}{l}\text { All reflective feedback } \\
\text { session interviews }\end{array}$ & $\begin{array}{l}\text { David and Paul } \\
\text { comment on their } \\
\text { lessons }\end{array}$ & \\
\hline \multirow{2}{*}{$\begin{array}{l}\text { 2) How did student } \\
\text { teachers experience } \\
\text { dialogic interaction } \\
\text { and its } \\
\text { implementation? }\end{array}$} & $\begin{array}{c}\text { Introductory lessons } \\
\text { of the teaching } \\
\text { program } \\
2008-2009 \\
\end{array}$ & $\begin{array}{l}\text { Student teachers } \\
\text { comment on previous } \\
\text { video-excerpts of } \\
\text { David and Paul } \\
\end{array}$ & \\
\hline & $\begin{array}{l}\text { Semi-guided group } \\
\text { interview of both } \\
\text { semesters }\end{array}$ & $\begin{array}{l}\text { Student teachers } \\
\text { discussions on the } \\
\text { teaching program and } \\
\text { dialogic teacher-talk }\end{array}$ & \\
\hline
\end{tabular}

Two lessons from each student teacher were video recorded and analyzed. The limited number of video recordings was due to two reasons: Firstly, student teacher lessons are often scheduled parallel to each other, thus there was a lack of researcher resources. Secondly, as the teaching program was integrated within an already intensive teacher training curriculum it was not desirable to strain student teachers with an excessive number of obligatory reflections and peer videoing. The codes for the video analysis were derived from the communicative approaches described by Mortimer and Scott (2003):

o Interactive Authoritative (I/A): Question-answer routines often feature in the I/A class with pupil responses often being evaluated in-line with the authoritative view of science leaving little space for the consideration of alternative or diverging ideas.

o Interactive Dialogic (I/D): Student ideas (e.g. everyday views) are intentionally explored and exploited with no evaluative aspect. When working within the I/D class the teacher does not seek a specific point of view, rather the teacher purposefully elicits student perspectives and works with these contrasting views. 
o Non-Interactive Authoritative (NI/A): The teacher explicitly presents the scientific view, often by lecturing, without addressing contrasting views.

o Non-Interactive Dialogic (NI/D): The teacher works with contrasting views, perhaps previously expressed pupil perspectives, and intentionally moves towards the scientific perspective. In the NI/D class while the teacher may lecture, diverging ideas are still present and the way in which the teacher-talk manages both the everyday and expert understandings means that the teacher-talk is dialogic in nature.

Coding was done each 20 seconds and 'micro-scale' indicators for the communicate approaches (e.g. teacher feedback) were considered, thus one minute in the figures could include several communicative approaches in terms of codes: For example, a dialogic episode could include authoritative passages which aim to guide the direction of discussions. An episode in general is defined by considering the activity, topic, teaching purpose and intervention taking place. Within a dialogic episode the predominant communicative approach is dialogic as defined by Mortimer and Scott (2003), although authoritative turns to guide the discussions may occur. The reliability and validity of our video analysis was checked by selected parts of lessons, including 'richly' different communicative approaches, being video coded by two coders independently. Cohen's Kappa was used to indicate the inter-rater reliability in conjunction with the statistical program SPSS. A Cohen's Kappa value of $0.788(\mathrm{p}<0.001)$ indicates that the inter-rater reliability can be considered satisfactory for our purposes. Differences in coding were discussed and when agreement was achieved the coding of those parts was revised. The primary tool used for the overall analysis was the AtlasTi-software which, whilst designed for qualitative analysis, can also be used for quantitative procedures. 
Extracts of transcribed talk from the activities listed in Table 2 allow readers to evaluate the analysis and findings presented in the following sections. The match between excerpts, themes and interpretations, were peer debriefed among the local community of educational researchers including the authors (Miles \& Huberman, 1994). Furthermore, international researchers within this line of work provided their commentary on the draft. The data was also shared with the student participants who responded to their university e-mail (Anthony, Joanna, George, Mark, Melanie and Paul) so that 'member check' of the transcriptions and interpretations was also applied in the validation process (Lincoln \& Guba, 1985).

\section{Findings}

\section{Research Question 1: How did student teachers plan and implement dialogic teacher-talk during their pre-service field practice?}

\section{Planning, implementation and reflection: individual student teacher examples.}

This section includes overviews (Figure 1) from Paul's and David's lessons, with one transcribed and translated episode from each lesson followed by student teacher and then researcher comments. These excerpts are also used in the later discussion on student teacher pre-conceptions of teacher-talk. David's example is from his first video-recorded lesson. At this point David had no detailed information why he was video-recorded. David and Kevin joined the teaching program during the first feedback session. Thus, they did not know they were being observed for the presence or absence of dialogic interactions during the first video- recorded lesson. In contrast Paul had specifically focused on the CA when planning his lesson. These different orientations to talk are visible in both the overviews of the lessons (45min) and in the feedback sessions. As can be seen in Figure 1 below, the structure of Paul's lesson indicates dialogic instances at several points in the lesson, whereas David's lesson includes only brief attempts to initiate dialogic 
interaction at the beginning of the lesson (coded as I/D turn at min 6, see excerpt below) and in the introduction to a new topic, electromagnetism (10-15min). Whereas David's lesson figure indicates one dialogic episode (10-15min), two dialogic episodes were confirmed in Paul's lesson (16-17min \& 33-35min). Coded dialogic turns in Paul's lesson between minutes 24-30 are not sufficient in constituting episodes as dialogic since the prevailing approach is still authoritative.

David



Paul

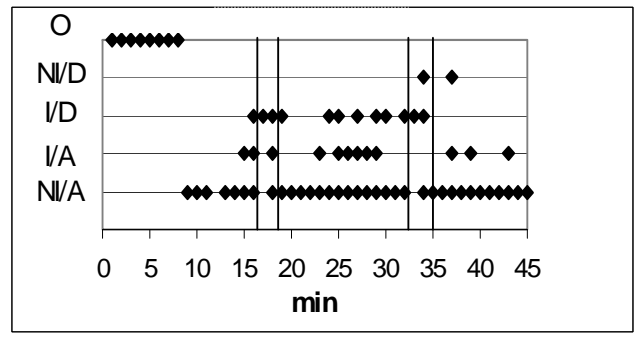

The horizontal axis shows time in minutes and the vertical axis the Communicative Approach: NI/A = non-interactive authoritative, $\mathrm{I} / \mathrm{A}=$ interactive authoritative, $\mathrm{I} / \mathrm{D}=$ interactive dialogic, NI/D = non-interactive dialogic. $\mathrm{O}$ stands for other actions such as general announcements from the central speaker. Dialogic episodes are displayed within vertical lines.

Figure1. Overviews of Paul's and David's lessons

David's Lesson Excerpt and Reflective Feedback Session: David's lesson in the training school was for $8^{\text {th }}$ grade $(14-15$ years) secondary school students. The following extract is from the beginning of a lesson on electricity and includes David giving neutral feedback to pupil responses. The absence of the extended implementation of dialogic talk is even more apparent when compared to Paul's excerpt illustrated later.

David’s lesson excerpt: Domestic devices in parallel

1 David: And how do you think the stereo system operates, if you think...don’t think too hard! If you have a flat-iron there and you are using it. You have the stereo system there and you 
disconnect the flat-iron...what happens to the stereo system? Well, no-one has that kind of stereo system anymore but anyhow... (pause). Does the volume get louder, as though more current would flow in there or...?

2 Student: It gets quieter, I guess.

3 David: Quieter? (repeats with rising intonation and waiting for an extension)

4 Charlie: Well, less current goes there...because then...there goes only that 0.2 amperes and that's why ...

5 David: If we think about that in a slightly different way...then the more apparatuses I plug in, the louder the stereo will be. For example, if I put another stereo system into that empty socket (shows picture) ...

6 Charlie: Well because there will be... more current would flow in the circuit.

7 David: Yes (not evaluating). ... The thing is...that the sockets...erm...Is it like...like...erm ...the current that flows in the circuit is for different stereo systems, so if you unplug one...or if you unplug that flat-iron, the efficiency of the stereo system still stays the same. In a way the stereo system has its own current that flows there... and the current stays the same. The current doesn't change...(pause). That is the correct answer. (Transcribed and translated by the $1^{\text {st }}$ author) 
Comments: The question about predicting what happens when the flat-iron is unplugged was neutral, open-ended (turn 1) and David's reaction to the student's incorrect answer was non-evaluative (turn 3). As the excerpt from the feedback session confirms, David acknowledged what the pupil had to say but after a short, clear pause moved the talk on emphasizing the correct answer:

David: There I made a mistake...I got feedback from my tutor teacher (Mrs. Hill). The camera just turned away when I was nodding all the time the pupil was giving an incorrect answer...He answered that if you disconnect the flat-iron then less current is conducted through the stereo system... Like the same current would have been conducted to every part of the circuit. And there I even said, “yes”. (Clearly not evaluating but declaratory)

Facilitator: So did you accept the answer?

David: Well...for some reason I didn't want to...I was somehow afraid that I would discourage him...I didn’t want to evaluate him immediately and for some reason. I just nodded and said “yes” although I didn’t accept the answer as a correct one. And I later presented, as far as I remember, what the correct answer was. (Transcribed and translated by the $1^{\text {st }}$ author)

This episode could be considered to include minor characteristics of dialogic interaction, such as the non-evaluative feedback. As David's comment reveals, however, he had no clear idea why to do this. David mentions not wanting to discourage the pupil, but his comments do not reveal awareness of other benefits this kind of prompting can lead to, on the contrary David and his tutor teacher (Mrs. Hill), considered it a mistake. From a sociocultural perspective, this excerpt can be seen as an (unintentional) attempt to initiate dialogue. David's lesson plan 
(Appendix A) revealed no intentional talk-based interaction or other discursive strategies. For David, as for many student teachers, the focus was on the lesson content and structure. These notions might be obvious, yet the importance of awareness and intentional planning for talkbased interaction needs to be highlighted to be realized.

Paul's Lesson Excerpt and Reflective Feedback Session: This episode includes a pre-planned dialogic episode, which Paul initiates with a simple demonstration of a bouncy rubber ball (min 33-35). Paul's lesson was part of the second physics course in upper secondary school on the topic of thermophysics. The lesson dealt with the laws of thermodynamics.

Paul's lesson excerpt: Bouncy rubber ball

$1 \quad$ Paul: What happens (drops the rubber ball)?

2 John: The energy of the ball is consumed.

$3 \quad$ Paul: $\quad$ Yes (not evaluating). Why is there energy loss?

4 Mike: $\quad$ For instance, air friction. Every time it goes up and down it affects it... its movement. (Students are putting their hands up)

$5 \quad$ Paul: $\quad$ Yes (not evaluating). Jake?

6 Jake: More energy goes to the floor.

$7 \quad$ Paul: $\quad$ And in what form does it go to the floor? Richard?

8 Richard: As heat.

$9 \quad$ Paul: $\quad$ As heat (repeating). And where else?

10 Michael: To the sound. We can hear the sound.

11 Paul: Does it make a sound (drops the ball). Yes...we can hear a sound. Other ideas? 
12 John: Against gravitation.

13 Paul: Against gravitation you said. And what does the energy convert to?

14 George: To potential energy.

15 Paul: Yes (not evaluating). It goes up...yes, but why doesn't it reach the same level?

16 Jake: The energy converts to another form.

17 Paul: Paul: Yes (evaluating). The energy converts to another form. And you said for example to heat, and many other forms. But when we think that energy loss occurs... Well some goes to the sound. But the rest... where does it go to? What does it convert to? Well, it has been said already... Richard?

18 Richard: To heat.

19 Paul: Yes, to heat! Through the friction of air...the energy changes its form to heat when the particles of air collide with the ball. The ball hits the floor and some of the heat goes to the floor and some of the heat to the ball. The kinetic energy converts slowly to heat. And in natural processes there is always some energy loss in the form of heat. (Transcribed and translated by 1 st author)

Comments: At the beginning of this episode, Paul listened to the students' ideas (turns 3, 5 \& 7), repeating them with a non-evaluative tone to ensure that everyone hears the answers (turns 9, 11 \& 13). The beginning of the episode is clearly dialogic and Paul's planned 
intervention was to elicit pupil views (Appendix A). After hearing the pupil responses, Paul reviewed their ideas (turn 17) before moving on and closing the dialogic interaction by foregrounding the scientific view with authoritative teacher-talk (turn 19).

When asked about planning and implementing the lessons in the reflective feedback session Paul explained:

Paul: When I was making the more detailed lesson plan I recognized quite quickly that there was an opportunity for dialogic talk... and in general because... I’ve been thinking about these things more and more, they come more naturally.

Facilitator: What do you think...If these things hadn't been brought up specifically, like you said, at this point in the normal pre-service curriculum...?

Paul: (Interrupts)...We would not think about these matters. When we are talking in feedback sessions with tutor teachers there are some things that they bring up. Like, does the teacher make an effort... or does he or she manage to pay attention to the pupils. These are the options. But in this program there is more thinking about how this could actually happen...

The episode involved Paul collecting pupil ideas with a non-evaluative tone (hence dialogic approach), however, the pupil ideas were taken no further. The dialogic level of this interaction, therefore, is considered low as was the case with other student teacher attempts to integrated dialogic interactions. Nevertheless, Paul's comments and lesson plan support the belief that he intentionally aimed to implement a dialogic approach. In contrast to David, Paul also 
reviewed the key concepts as they emerged and emphasized the scientific perspective effectively to conclude the dialogic interaction.

Summary of the Lesson Plans and Lessons. The video analysis process involved the identification of possible dialogic episodes. These dialogic episodes were then confirmed by checking the lesson plans and reflective feedback sessions in terms of purpose and intentionality. As illustrated in Table 3, Paul as well as 6 other student teachers did intentionally plan and implement dialogic approaches. The episodes were usually the same as introduced in Paul's excerpt: the student teachers used non-evaluative feedback to collect ideas from several pupils, but deeper exploration of these views did not take place and pupil turns were rather short. Three of the student teachers, Maria, Mark and Susan, were unable to implement dialogic approaches at the level they had planned, although dialogic attempts were made, as illustrated with David's case, and no extended dialogic episodes occurred fulfilling the dialogic criteria of the CA, as Paul's case illustrates.

With reference to Table 3, as Lea participated in the program with the proviso of no video recording she is not included. George’s lessons were unfortunately rescheduled several times due to cancellations by the teacher training school and consequently the video-recording of his lessons could not be realized. This was also the case with Maria’s second lesson. David and Kevin joined the teaching program later than the other participants. They were introduced to the CA during the first reflective feedback session, thus they had no explicit communication plans for the first lesson. 
Table 3 Number of dialogic episodes in lesson plans and lessons

\begin{tabular}{lcccc} 
& \multicolumn{2}{c}{ Lesson 1 } & \multicolumn{2}{c}{ Lesson 2 } \\
\hline Student teacher & $\begin{array}{c}\text { Lesson } \\
\text { plan }\end{array}$ & Lesson & $\begin{array}{c}\text { Lesson } \\
\text { plan }\end{array}$ & Lesson \\
\hline Anthony & 3 & 2 & 2 & 1 \\
\hline George & - & - & - & - \\
\hline David & $0^{*}$ & $1^{*}$ & 1 & 1 \\
\hline Kevin & $0^{*}$ & $1^{*}$ & 4 & 2 \\
\hline Maria & 2 & 0 & - & - \\
\hline Paul & 3 & 2 & 1 & 1 \\
\hline Susan & 3 & 0 & 1 & 0 \\
\hline Joanna & 1 & 1 & 1 & 1 \\
\hline Mark & 1 & 0 & 1 & 0 \\
\hline Melanie & 1 & 1 & 1 & 0 \\
\hline Rosanna & 2 & 1 & 2 & \\
\hline$*=$ CA not intentionally planned/implemented & & \\
-=not available due to rescheduling & & & 1 \\
\hline
\end{tabular}

\section{Research Question 2: How did student teachers experience dialogic interaction and its implementation?}

\section{Collective Responses: Student Teacher Comments on the Video-Excerpts of}

David and Paul. During the initial program 2007-2008 some student teachers experienced difficulties when observing and commenting on peer teaching episodes. In response to this the video-clips of David and Paul were used in the introductory lessons of 2008-2009 from the video databank. The purpose was to map student teacher views on these clips before introducing and practicing the CA. George, for example, commented on Paul's video clip saying, "It started a bit shaky, but in the end everything was correct.” By "a bit shaky” George presumably refers to Paul's non-evaluative responses when the pupil ideas were collected. At the same time Paul's firm closure was appreciated. The student teacher comments indicate no awareness of dialogic interaction (including David in the feedback session). Even though Paul's episode includes clear characteristics of a dialogic interaction, as shown earlier, initially the student teachers showed no 
appreciation of this feature. The pre-conceptions expressed here confirmed the major concerns of the student teachers as correctness and establishment of the lesson content.

\section{Student Teacher Discussion of the Teaching Program and Dialogic Interaction.}

This section presents the major themes and subthemes with frequencies based on the groupinterview data (Table 4). Group-interviews were used to provide an opportunity for the student teachers to build upon the comments of their peers in dialogic interaction. In this interactive context, memories can more easily be refreshed and fruitful insights into student perspectives and perceptions can be more readily obtained (Borko, Mayfield, Marion, Flexer, \& Cumbo, 1997; Eybe \& Schmidt, 2004). Using the principles of the data-driven thematic approach the main themes included in the table below were identified: Interesting features of the data were coded in systematic fashion and in stages collated into major themes and subthemes (Braun \& Clarke, 2006, p. 87). Table 5 contains illustrative examples and data extracts for each subtheme. The subthemes are numerically ordered linking them with the following illustrative examples. For example George's comment in rows 4 and 5 depicts his views about the challenges of developing with dialogic implementation. 
Table 4 Themes and frequencies produced from group-interviews

\begin{tabular}{|c|c|c|c|}
\hline Research question 2 & Major theme & Subtheme & Frequency \\
\hline \multirow{7}{*}{$\begin{array}{l}\text { How did student teachers } \\
\text { experience dialogic } \\
\text { interaction and its } \\
\text { implementation? }\end{array}$} & \multirow{3}{*}{ Increased awareness(14) } & $\begin{array}{l}\text { 1) Awareness of DI } \\
\text { increased(6) }\end{array}$ & $\begin{array}{l}\text { George(2), David(2), } \\
\text { Kevin(1), Paul(1) }\end{array}$ \\
\hline & & $\begin{array}{l}\text { 2) Awareness of the } \\
\text { effects of the DI } \\
\text { increased (e.g., } \\
\text { atmosphere)(3) }\end{array}$ & $\begin{array}{l}\text { Anthony(1), Kevin(1), } \\
\text { Maria(1) }\end{array}$ \\
\hline & & $\begin{array}{l}\text { 3) Awareness of } \\
\text { different roles in CA } \\
\text { increased(5) }\end{array}$ & $\begin{array}{l}\text { Anthony(1), George(1), } \\
\text { Joanna(1), Paul(2) }\end{array}$ \\
\hline & \multirow{4}{*}{$\begin{array}{l}\text { Challenges to dialogic } \\
\text { teaching }(18)\end{array}$} & $\begin{array}{l}\text { 4) Question of } \\
\text { discipline(5) }\end{array}$ & $\begin{array}{l}\text { George(3), Joanna(1), } \\
\text { Maria(1) }\end{array}$ \\
\hline & & 5) Question of time(4) & $\begin{array}{l}\text { George(1), Joanna(2), } \\
\text { Mark(1) }\end{array}$ \\
\hline & & $\begin{array}{l}\text { 6) Insufficient content } \\
\text { knowledge(5) }\end{array}$ & $\begin{array}{l}\text { Maria(2), David(1), } \\
\text { Kevin(1), Lea(1) }\end{array}$ \\
\hline & & $\begin{array}{l}\text { 7) Insufficient } \\
\text { pedagogical content } \\
\text { knowledge(4) }\end{array}$ & $\begin{array}{l}\text { Maria(1), George(2), } \\
\text { Joanna(1) }\end{array}$ \\
\hline \multirow[t]{2}{*}{ Additional themes } & \multirow[t]{2}{*}{ Videos(16) } & $\begin{array}{l}\text { 8) Videos were } \\
\text { useful(11) }\end{array}$ & $\begin{array}{l}\text { Anthony(1), David(1), } \\
\text { Kevin(1), Maria(2), } \\
\text { Mark(1), Melanie(2), } \\
\text { Rosanna(1), Susan(2) }\end{array}$ \\
\hline & & $\begin{array}{l}\text { 9) More video-recorded } \\
\text { lessons(5) }\end{array}$ & $\begin{array}{l}\text { Joanna(2), Kevin(2), } \\
\text { Susan(1) }\end{array}$ \\
\hline
\end{tabular}




\section{Table 5 Descriptions and examples of subthemes (No.= subtheme number)}

\begin{tabular}{|c|c|c|}
\hline No. & Description & Data extract \\
\hline 1 & $\begin{array}{l}\text { Student teacher indicates } \\
\text { increased awareness of dialogic } \\
\text { options at a general level }\end{array}$ & $\begin{array}{l}\text { David: I found that this was very useful... and from this brief experience I can } \\
\text { say that this kind of approach is something that is likely forgotten. The teaching } \\
\text { is mainly lecturing. This tool feels like something that I'm going to keep in-mind } \\
\text { while in-service. }\end{array}$ \\
\hline 2 & $\begin{array}{l}\text { Student teacher recognizes one } \\
\text { or more features that dialogic } \\
\text { interaction could have a positive } \\
\text { influence. E.g. creating an open } \\
\text { atmosphere in the classroom. }\end{array}$ & $\begin{array}{l}\text { Maria: I've been thinking about many of these things discussed here also. But } \\
\text { what Kevin said about interaction, about the communicative approaches... that } \\
\text { they create a certain atmosphere. That kind of atmosphere affects other things } \\
\text { too. Even though at times the dialogic phase doesn't take place, that kind of } \\
\text { relaxed atmosphere occurs in other situations also. It might have a positive effect } \\
\text { in general... it doesn't matter if the teaching is lecturing at some points... and it } \\
\text { should be every now and then. But even in those situations the atmosphere for } \\
\text { learning stays comfortable. I noticed that during the observations in the Teacher } \\
\text { Training School. And when I paid attention to some teachers' styles I discovered } \\
\text { that in those lessons where... there were more discussions... well, those parts } \\
\text { went more smoothly. }\end{array}$ \\
\hline 3 & $\begin{array}{l}\text { Student teacher indicates } \\
\text { increased awareness about the } \\
\text { different roles with regard to } \\
\text { CA e.g. dialogic interaction to } \\
\text { collect pupil views and } \\
\text { authoritative approach to } \\
\text { introduce the science view. }\end{array}$ & $\begin{array}{l}\text { Paul: Yes. I thought it was useful to think about the communicative approaches } \\
\text { and what kind of talk belongs where. I've been thinking about these things in } \\
\text { more than just the video-recorded lessons. I think this has even made my lessons } \\
\text { more coherent. There has been some kind of structure in the background and I've } \\
\text { been able to include more dialogic approaches in my teaching. The very first } \\
\text { teaching sessions were mostly lecturing at the beginning of the autumn... but } \\
\text { because I involved myself with this project, I've been able to vary my talk and } \\
\text { recognize what kind of talk could be used in specific situations... }\end{array}$ \\
\hline 4 & $\begin{array}{l}\text { For instance, student teacher } \\
\text { indicates concern dialogic } \\
\text { approaches leading to } \\
\text { disciplinary problems. }\end{array}$ & $\begin{array}{l}\text { George: I really think that teachers turn to survival mode and other things... But } \\
\text { firstly, about the talk or dialogues, we do not even discuss that much here during } \\
\text { the pre-service period, and if you have taught for many years you will forget } \\
\text { those small details and you will take the easiest way to survive from the lessons. }\end{array}$ \\
\hline 5 & $\begin{array}{l}\text { Student teacher indicates that } \\
\text { implementing a dialogic } \\
\text { approach takes too much time }\end{array}$ & $\begin{array}{l}\text { George continues: And peer discussions could be sometimes frustrating, when } \\
\text { you feel that the discourse doesn't proceed and you start to respond to your own } \\
\text { questions and again one lesson is behind. } \\
\text { Joanna: I don't know if it is really so, that if a teacher teaches dialogically, that it } \\
\text { would in every case be slower than when the teacher is teaching by lecturing... } \\
\text { is it always inevitable? [Lea: I'm sure it isn't.] }\end{array}$ \\
\hline 6 & $\begin{array}{l}\text { Student teacher indicates that } \\
\text { one must have sufficient content } \\
\text { knowledge to feel confident in } \\
\text { engaging in dialogic discussions }\end{array}$ & $\begin{array}{l}\text { Lea: I'm sure it isn't. When you think for example about Mr. James, who in my } \\
\text { opinion can teach dialogically, and those lessons in my opinion are very good... } \\
\text { It requires very in-depth subject knowledge... }\end{array}$ \\
\hline 7 & $\begin{array}{l}\text { For instance, the student teacher } \\
\text { indicates that s/he has } \\
\text { insufficient prior knowledge of } \\
\text { pupils' misconceptions, in order } \\
\text { to be able to guide dialogic } \\
\text { discussions appropriately. }\end{array}$ & $\begin{array}{l}\text { Joanna: I just discussed this in that small scale study, because at no phase of the } \\
\text { pre-service period are you told what kind of prior knowledge pupils have. And } \\
\text { you are also in trouble yourself when you try to discuss when necessary... And } \\
\text { there might be questions you cannot answer... And for sure, some of those } \\
\text { questions come up frequently every year... So if you have taught one or two } \\
\text { times you could know how to answer. I was wondering if I would have felt the } \\
\text { dialogic discourse easier, if I'd had some material or background reading where } \\
\text { there were dialogues that possibly would emerge. }\end{array}$ \\
\hline 8 & $\begin{array}{l}\text { Student teacher indicates videos } \\
\text { being useful in reflection or/and } \\
\text { analysis }\end{array}$ & $\begin{array}{l}\text { David: After the lesson you might think that there were a lot of discussions, but } \\
\text { after seeing the video you might notice you merely had a dialogue with yourself. }\end{array}$ \\
\hline 9 & $\begin{array}{l}\text { Student teacher indicates the } \\
\text { need for more videos. (Mostly } \\
\text { related to their own teaching) }\end{array}$ & $\begin{array}{l}\text { Susan: It would have been nice to see lessons right from the beginning and } \\
\text { compare them to the later ones. }\end{array}$ \\
\hline
\end{tabular}


Comments: Themes 1-3 address student teachers’ increased awareness with regard to the CA. When they discussed dialogic teaching they usually referred to the dialogic approach, which we consider one practical application of the CA. Theme 1 was constructed from student teacher comments that did not specify features of the dialogic interaction, instead the student teachers just noted that their awareness about dialogic options, had increased. The most common effect was the dialogic approach creating a classroom climate where pupils have opportunities to discuss and pose questions themselves. Theme 3 addresses the issue highlighting the role of different approaches in science teaching, for example, that the dialogic approach does apply to every instance, thus the authoritative approach also has its place in science education.

Themes 4-6 on the challenges of dialogic teaching were as anticipated addressing relatively familiar issues of insufficient pedagogical and content knowledge. The reflections of theme 7 indicate how research could contribute to classroom interaction and how classroom interaction requires a higher level of understanding. This kind of reflection could be seen to relate to pedagogical content knowledge (Abell, 2007; Shulman, 1986) and misconceptions, for instance, could be effective stimulants to engage pupils in challenging their own views if addressed purposefully.

The frequencies reveal that seven student teachers indicated increased awareness of communicative options, particularly dialogic approaches. With regard to the major theme challenges, Mark also contributed to the discussion. Susan and Rosanna did not comment directly on the major themes, although they did mention the usefulness of videos, the additional theme most frequently identified.

\section{Discussion}


The aim of the study was to examine science student teachers’ physics lessons during their initial field experience and explore student teacher experiences when planning and implementing dialogic approaches. Lesson plans, lessons and reflective feedback sessions revealed that student teachers are able to challenge the traditional forms of teaching by including untypical (Mercer et al., 2009) dialogic approaches in their field practice. The additional group-interviews shed light on these experiences, highlighting the positive influence of the dialogic teaching program on student teachers' awareness of teacher-talk (themes 1-3). The student teacher perceptions prior to the program proved to focus firmly on content specific features rather than on the interaction between teacher and pupils. Within the program, videos were acknowledged to be significant agents when addressing different communicative aspects (themes 8 \& 9).

David implemented a dialogic approach without any prior knowledge of the CA. His lack of awareness or purposefulness in using dialogic talk was apparent in his lesson plan and reflection, as well as in the lesson video. Whereas David's lesson mostly resembled traditional lecturing, Paul intentionally varied his classroom communications, evidenced in his planning, practice and reflection. The fact that not every student teacher was able to implement dialogic approaches in practice, regardless of their planned intentions, signals how challenging it is for student teachers to silence the authoritative voice of science, and to mediate dialogic interactions, especially during whole class discussions (Scott, Ametller, Mortimer, \& Emberton, 2009). The implementation of dialogic approaches was mostly limited to the collection of pupil ideas rather than further exploration of these ideas. This may well indicate that student teachers lack confidence in their level of content knowledge (theme 6), an issue in-service teachers struggle with too (Childs \& McNicholl, 2007; Colucci-Gray \& Fraser, 2008). The student teachers also frequently brought up other reasons as to why dialogic approaches were not adopted with 
discipline and timing presented as the most important factors (themes 4 \& 5). This conflict was voiced by George, who indicated an increased awareness of the CA on a general level and yet was also very skeptical of the challenges of implementing dialogic approaches in-service. Paul did not share this skepticism, however, possibly because his positive experiences and successful dialogic episodes inspired him with the confidence that dialogic interaction in future classes was attainable.

In relation to pedagogical challenges (themes 4 \& 5), Kagan (1992) argues that before student teachers can adopt new insights into their teaching, their classroom management skills should be already established. Our findings agree instead with Grossman (1992), who stresses that if student teachers are supposed to go beyond the technical aspects of teaching and question their practice, they should be guided towards doing so:

If our goal is not helping prospective teachers attain an immediate mastery of classroom routines, but preparing prospective teachers to ask worthwhile questions of their teaching, to continue to learn from their practice, to adopt innovative models of instruction, and to face the dimensions of classroom teaching, then we must place our emphasis elsewhere. (p. 176)

The results of this study indeed indicate that although student teachers are concerned about discipline and time, they are capable of challenging traditional forms of classroom interaction during their pre-service in both theory and practice. Nevertheless, as these findings indicate, for student teachers to successfully adopt innovative teaching methods, a significant amount of support is required.

The interview data reveal that although the main concerns of student teachers remain lesson content and discipline, another dimension to their views on teaching and learning 
had developed. The notion of dialogic interaction was shared with the student teachers as an important part of the broader Communicative Approach (Mortimer \& Scott, 2003). The student teachers considered this approach useful in lesson planning and execution, as well as a useful tool in the analysis of videoed lessons. This finding relates to the most frequently identified additional themes 8 and 9 which confirm the role of videos as an essential and influential element in the intervention program. The student teachers reported that in addition to watching the videos, the reflections paying attention to specific features such as questioning and communicative options, for example, were extremely constructive. In relation to the limitation acknowledged before, surprisingly, also the student teachers wanted even more lessons to be filmed, a striking change from the beginning of the program. It may be that as a result of the program, the student teachers adopted a more analytical approach to their teaching. These findings suggest that this program which sought to dialogically share a new communicative approach formed a gestalt forum within which the student teachers could collaboratively share their views. This style of intervention may be particularly relevant if teachers feel insecure about adopting new methods of teaching (Meirink, Meijer, \& Verloop, 2007). This program cannot, however, be considered as completely independent from its context, as indicated by the tutor teacher's comments and Paul's references to other external influences on the lesson content and execution.

\section{Implications}

This project has reinforced our prior assumptions that student teachers have difficulties understanding broader educational theories and their relevance in everyday teaching. Sociocultural aspects of teaching and learning are included in the curriculum but dialogic teaching and its practical applications are rarely highlighted, detailed, and practiced during field practice. On the basis of this study, the following suggestions aim to address this discrepancy: 
- Instead of extensive time spent on broader educational theories about classroom interaction, student teachers should be introduced to specific scholarly descriptions of teacher-talk (such as the CA and IRF-sequence), in order to make different approaches explicit;

- Scholarly descriptions of teacher-talk should be used to train student teachers thoroughly with videos before using them in planning, real time observations, analysis and reflection;

- Overview figures (see figure 1) of lessons could be powerful tools to structure constructive feedback for teachers (Viiri \& Saari, 2006);

- $\quad$ Although videos are powerful stimulants to trigger reflections (O’Brien, 1993) they should be used with an analytical tool, such as the CA offers, to prevent irrelevant selfcritical focus on secondary features of student teacher behavior (Levin, Hammer, \& Coffey, 2009);

- $\quad$ Teachers should be provided with material including exemplary dialogic discussions and some general/specific hints (e.g. possibly emerging misconceptions) for planning and implementing these approaches. Furthermore, teachers should be provided with information about how to deal with emerging understandings in order to engage in educationally-purposeful extended dialogues (a limitation also noted within this study).

The prior notions of the student teachers made more visible in this study should be examined more extensively in forthcoming studies. Furthermore the inductive and practical approach to sociocultural theory of teaching and learning introduced in this paper could be continued as a part in-service practice. The threat does exist that real school culture could lead to regression; however, some teachers working independently in their classes have demonstrated the 
ability to continue professional development when well-prepared for reform (Franke, Carpenter, Levi, \& Fennema, 2001). In Franke et al.’s study, teachers kept pupil thinking in the center when it came to their beliefs and practice about teaching and learning. As the student teachers in this study were profoundly concerned about classroom control, we hope that they will see talk as a tool for learning in the future. This issue will be examined in a longitudinal study involving some of the participants of the program when working as in-service science teachers.

Despite the previously listed procedures intended to maintain the objectivity of this study, as the first author led the intervention teaching program (necessary for the project) subjectivity within our research (Peshkin, 1988) is to some degree inevitable. Nevertheless, we still regard the findings of this study to have identified interesting issues, contributing valuable topics for further research within this area. Finally, we suggest that the topic and the content of the intervention program introduced in this paper could contribute to the professional development of all teachers not science teachers alone.

\section{Acknowledgements}

Lehesvuori gratefully acknowledges the financial support of the Finnish Cultural Foundation. Rasku-Puttonen was funded by the Academy of Finland, No. 130707. The work was also funded by the project of Academy of Finland, No. 132316. With thanks to Josephine Moate for her language support.

\section{References}

Abell, S. (2007). Research on science teacher knowledge. In S. Abell \& N. Lederman (Eds.), Handbook of research on science education (pp. 1105-1149). Mahwah, NJ: Lawrence Erlbaum Associates.

Abell, S. K. (Ed.). (2000). Science teacher education: An international perspective. Dordrecht, The Netherlands: Kluwer Academic Publishers. 
Akerson, L. V., \& Hanuscin, D. L. (2007). Teaching nature of science through inquiry: Results of a three year professional development program. Journal of Research in Science Teaching, 44(5), 653-680.

Alexander, R. (2006). Towards dialogic teaching (3 ${ }^{\text {rd }}$ ed.). York: Dialogos.

Borko, H., Mayfield, V., Marion, S., Flexer, R., \& Cumbo, K. (1997). Teachers’ developing ideas and practices about mathematics performance assessment: Successes, stumbling blocks, and implications for professional development. Teaching and Teacher Education, 13(3), 259-278.

Borko, H. (2004). Professional development and teacher training: Mapping the terrain. Educational Researcher, 33(8), 3-15.

Borko, H., Jacobs, J. K., Eiteljorg, E., \& Pittman, M. E. (2008). Video as a tool for fostering productive discussions in mathematics professional development. Teaching and Teacher Education, 24(2), 417-436.

Bransford, J., Darling-Hammond, L., \& LePage, P. (2005). Introduction. In L. Darling-Hammond \& J. Bransford (Eds.), Preparing teachers for a changing world: What teachers should learn and be able to do (pp. 1-39). San Francisco: Jossey-Bass.

Braun, V., \& Clarke, V. (2006). Using thematic analysis in psychology. Qualitative Research in Psychology, 3(2), 77-81.

Brophy, J. (Ed.) (2004). Using video in teacher education. Amsterdam: Elsevier.

Childs, A., \& McNicholl, N. (2007). Investigating the relationship between subject content knowledge and pedagogical practice through the analysis of classroom discourse. International Journal of Science Education, 29(13), 1629-1653.

Chin, C. (2007). Teacher questioning in science classrooms: Approaches that stimulate productive thinking. Journal of Research in Science Teaching, 44(6), 815-843. 
Chval, K., Abell, S., Pareja, E., Musikul, K., \& Ritzka, G. (2008). Science and mathematics teachers' experiences, needs, and expectations regarding professional development. Eurasia Journal of Mathematics, Science \& Technology Education, 4(1), 31-43.

Clarke, D., \& Hollingsworth, H. (2002). Elaborating a model of teacher professional growth. Teaching and Teacher Education, 18(8), 947-967.

Colucci-Gray, L., \& Fraser, C. (2008). Contested aspects of becoming a teacher: Teacher learning and the role of subject knowledge. European Educational Research Journal, 7(4), 475-486.

Crespo, S. (2002). Praising and correcting: Prospective teachers investigate their teacherly talk. Teaching and Teacher Education, 18(6), 739-758.

Eybe, H., \& Schmidt, H.-J. (2004). Group discussions as a tool for investigating students' concepts. Chemistry Education: Research and Practice, 5(3), 265-280.

Fajet, W., Bello, M., Leftwich, S. A., Mesler, J. L., \& Shaver, A. N. (2005). Pre-service teachers’ perceptions in beginning education classes. Teaching and Teacher Education, 21(6), 717-727.

Franke, M. L., Carpenter, T. P., Levi, L., \& Fennema, E. (2001). Capturing teachers’ generative growth: A follow-up study of professional development in mathematics. American Educational Research Journal, 38(3), 653-689.

Furtak, E. M., \& Shavelson, R. J. (2009). Guidance, conceptual understanding, and student learning: An investigation of inquiry-based teaching in the US. In T. Janik \& T. Seidel (Eds.), The power of video studies in investigating teaching and learning in the classroom. Munich: Waxmann.

Graber, K. C. (1996). Influencing student beliefs: The design of a 'high impact' teacher education program. Teaching and Teacher Education, 12(5), 451-466. 
Grossman, P. L. (1992). Why models matter: An alternate view on professional growth in teaching. Review of Educational Research, 62(2), 171-179.

Hartford, J., \& MacRuairc, G. (2008). Engaging student teachers in meaningful reflective practice. Teaching and Teacher Education, 24(7), 1884-1892.

Kagan, D. (1992). Professional growth among preservice and beginning teachers. Review of Educational Research, 62(2), 129-169.

Lemke, J. L. (1990). Talking science: Language, learning and values. Norwood: Ablex Publishing Company.

Levin, D. M., Hammer, D., \& Coffey, J. E. (2009). Novice teachers’ attention to student thinking. Journal of Teacher Education, 60(2), 142-154.

Lincoln, Y. S., \& Guba, E. G. (1985). Naturalistic inquiry. Beverly Hills, CA: Sage Publications, Inc.

Littleton, K., \& Howe, C. (Eds.) (2009). Educational dialogues: Understanding and promoting productive interaction. London: Routledge.

Luera, G., \& Otto, C. (2005). Development and evaluation of an inquiry-based elementary science teacher education program reflecting current reform movements. Journal of Science Teacher Education, 16(3), 241-258.

Meirink, J. A., Meijer, P. C., \& Verloop, N. (2007). A closer look at teachers’ individual learning in collaborative settings. Teachers and Teaching: Theory and Practice, 13(2), 145-164.

Mercer, N., Dawes, L., \& Staarman, K. (2009). Dialogic teaching in the primary science classroom. Language and Education, 23(4), 353-369.

Miles, M. B., \& Huberman, A. M. (1994). Qualitative Data Analysis (2 ${ }^{\text {nd }}$ ed.). Thousand Oaks, CA: Sage Publications. 
Molinari. L., \& Mameli. C. (2010). Classroom dialogic discourse: An observational study. Procedia - Social and Behavioral Sciences, 2(2), 3857-3860.

Mortimer, E. F., \& Scott, P. (2003). Meaning making in science classrooms. Milton Keynes: Open University Press.

Nystrand, M., Gamoran, A., Kachur, R., \& Prendergast, C. (1997). Opening dialogue: understanding the dynamics of language and learning in the English classroom. New York: Columbia University.

O’Brien, J. (1993). Action research through stimulated recall. Research in Science Education, 23(1), 214-221.

Oliveira, A. W. (2009). Developing elementary teachers’ understandings of hedges and personal pronouns in inquiry-based science classroom discourse. Journal of Research in Science Education, 8(2), 247-269.

Oliveira, A. W. (2010). Improving teacher questioning in science inquiry discussions through professional development. Journal of Research in Science Teaching, 47(4), 422-453.

Orland-Barak, L., \& Yinon, H. (2007). When theory meets practice: What student teachers learn from guided reflection on their own classroom discourse. Teaching and Teacher Education, 23(6), 957-969.

Peshkin, A. (1988). In search of subjectivity-one’s own. Educational Researcher, 17(7), 17-21.

Peters, E. E. (2010). Shifting to a student-centered science classroom: An exploration of teacher and student changes in perceptions and practices. Journal of Science Teacher Education, 21(3), 329-349. 
Posner, G. J., Strike, K. A., Hewson, P. W., \& Gertzog, W. A. (1982). Accommodation of a scientific conception: Toward a theory of conceptual change. Science Education, 66(2), 211227.

Rosaen, C., Lundeberg, M., Cooper, M., Fritzen, A., \& Terpstra, M. (2008). Noticing noticing: How does investigation of video records change how teachers reflect on their experiences? Journal of Teacher Education, 59(4), 347-360.

Schön, D. A. (1983). The reflective practitioner: How professionals think in action. New York: Harper Collins.

Scott, P. H., Mortimer, E. F., \& Aguiar, D. G. (2006). The tension between authoritative and dialogic discourse: a fundamental characteristic of meaning making interactions in high school science lessons. Science Education, 90(3), 605-631.

Scott, P., \& Ametller, J. (2007). Teaching science in a meaningful way: striking a balance between ‘opening up’ and ‘closing down’ classroom talk. School Science Review, 88(324), 77-83.

Scott, P., Ametller, J., Mortimer, E., \& Emberton, J. (2009). Teaching and learning disciplinary knowledge: Developing the dialogic space for an answer when there isn’t even a question. In K. Littleton \& C. Howe (Eds.), Educational dialogues: Understanding and promoting productive interaction (pp. 322-337). London: Routledge.

Shulman, L. S. (1986). Those who understand: Knowledge growth in teaching. Educational Researcher, 15(2), 4-14.

Sinclair, J., \& Coulthard, R. M. (1975) Towards an analysis of discourse. Oxford: Oxford University Press. 
Viiri, J., \& Saari, H. (2006). Teacher talk patterns in science lessons. Use in teacher education. Journal of Science Teacher Education, 17(4), 347-365.

Wells, G., \& Arauz, R. (2006). Dialogue in the classroom. Journal of the Learning Sciences, 15(3), 379428.

Yilmaz-Tuzun, O. (2008). Preservice elementary teachers’ beliefs about science teaching. Journal of Science Teacher Education, 19(2), 183-204.

van Zee, E. H., Iwasyk, M., Kurose, A., Simpson, D., \& Wild, J. (2001). Student and teacher questioning during conversations about science. Journal of Research in Science Teaching, 38(2), 159-190. 


\section{Appendix A}

\section{David's and Paul's Lesson Plans}

David: Lesson plan Tue 4.12.2007, Mrs. Hill, Secondary school's electric course

Structure

1. Introduction (of David) (5min)

2. Check homework (10min) (workbook, p.73, task 9 and textbook p.213, tasks 4 \& 5) (Note: Data extract)

3. Theory (15min)

4. Experimental group work 1 (15min) Notice proper explanations and reviewing (End of first lesson/Recess)

5. Experimental group work 2 (15min)

6. Demonstration (20min)

7. Experimental group work $3(10 \mathrm{~min})$ skip if necessary

8. Tasks (workbook p.81 tasks $1 \& 3$ )

Theory

- magnet has north- and south pole

- $\quad$ similar poles reject each other and different poles attract each other

- magnet creates a magnet field

- $\quad$ this field can be modeled with field vectors

- $\quad$ magnets and magnetic matters interact via magnetic field

- For example Earth has a magnetic field that protects us from harmful particles coming from the Sun

- Magnetizing means that for instance iron nail is turned to permanent magnet by using another

\section{Experimental group works and demonstrations}

1. Experimental group work 1: Workbook p.74, task 1

2. Experimental group work 2: Workbook p.75, task 2

3. Demonstration: Workbook p.77, task 4

4. Experimental group work 3: Workbook p.79, task 5

Paul: Lesson plan Wed 12.12.2007, Mr. James, Upper Secondary Course nr.2, duration 9:50-11:25

Topic

- Checking of the homework

- A brief introduction

\begin{tabular}{ll}
\hline - Teaching new topic: & - Teach the concept of \\
Entropy & entropy
\end{tabular}

- Demonstration
Purpose

- Review the content of the
previous lesson entropy

Implementation

- Pupils present their tasks in the front - Discussions about tasks and problems

- Discussions about everyday phenomena involving entropy

- Figure out together what entropy is - A drop of color ingredient spreads to a water tank

- Discuss about phenomena

- Teaching new topic: energy conversion and the third law of thermodynamics

- Teach the concept of the
energy conversion and the
third law of
thermodynamics

- Demonstration with a
rubber ball to initiate thoughts

- Figure out the new topics with the assistance from the pupils

- Energy in society $\left(2^{\text {nd }}\right.$ half of the double lesson, not in the lesson figure)
- To get pupils motivated to seek the information
- Getting familiar with greenhouse effect via slideshow

- A group work

- Reviewing together

\section{Communicative} approach

Teacher presentation (NI/A) and authoritative discussion (I/A)

Dialogic discussion (I/D)

Teacher presentation (NI/A)

Dialogic discussion (I/D) and teacher presentation (NI/A)

Dialogic discussion (I/D)

(Note: Data extract) and teacher presentation (NI/A)

Teacher presentation (NI/A)

Peer discussions Dialogic discussions (I/D) 